\title{
Effectiveness of Bodong as an Alternative Dispute Resolution: A Glimpse of Kalingas' Peace Framework
}

\author{
Rudolf T. Vecaldo ${ }^{1, *}$, Romeo C. Clemente ${ }^{1}$, Agustin Y. Tamangen ${ }^{2}$ \\ ${ }^{1}$ Cagayan State University, Andrews Campus, Philippines \\ ${ }^{2}$ Philippine National Police Regional Command, RO-2, Philippines
}

Copyright (c) 2015Horizon Research Publishing All rights reserved.

\begin{abstract}
Bodong, a peace pact, evolves from the customs and traditions of the Kalingas. It discloses indigenous people's cultural identity, heritage and integrity that were painstakingly developed with the passing of the time. This study investigated the effectiveness of bodong as an alternative dispute resolution that reflects the peace framework of the community in dealing with crimes and tribal-related offenses in the province of Kalinga, Philippines. With 305 respondents composed of local officials, court employees, law enforcers and tribal leaders, findings significantly confirm bodong as an effective system of enforcing peace because it does not in a way oppose to the realms of existing laws. Thus, for bodong system to sustainably advance social security and economic stability of culturally diverse tribes, key stakeholders should constitute bolder steps in coming up with success indicators on the intensive education campaign regarding the provisions of pagta not only to binodngans but also to non-binodngans.
\end{abstract}

Keywords Kalinga, Bodong, Binodngans, Pagta, Alternative Dispute Resolution

\section{Introduction}

Peace operates in the presence of social justice and in the absence of misunderstanding, conflict and war. It functions for stability, orderliness and harmony in the society, Lang-ay et.al. ${ }^{[1]}$. Peace, in that case, is the ultimate necessity for the attainment of an authentic, holistic and sustainable development. Without it, society disintegrates and eventually leads to a certain state of ruination. Hence, no matter how diverse people may be in terms of socio-cultural orientations, they are duty bound to push straightforward the dynamic efforts to keep on working fervently in the pursuit of peace and justice. Consequently, in a complex human civilization, there is a pressing need for peace to serve as the solid foundation so that solidarity becomes evident that relatively spells out the common tract for inclusive growth and genuine societal development.
On the other hand, it is inevitable that in some instances, misunderstanding, conflict and even wars exists. These are basically part and parcel of human realities. They are already intertwined in the fabric of human existence. Nevertheless, in all societies, it is common for people to look for shared substantive norms to resolve problems, Lang-ay et.al. ${ }^{[1]}$.

The preceding premises point to the significant role of alternative dispute resolution (ADR). According to Mnookin ${ }^{[2]}$, ADR is a set of practices and techniques aimed at permitting the resolution of disputes, basically legal in nature, outside the courts. It covers mediation, arbitration and other informal processes by which disputes are resolved in a neutral ground without formal adjudication. Shavel ${ }^{[3]}$ shares that when parties need to resolve disputes; they may turn not only to trial before courts but also to alternative dispute resolution. In ADR, a third party is involved who offers an opinion or communicates the information about disputes to the disputants.

In the Northern Philippines, one of the provinces situated in the Cordillera Administrative Region (CAR) that embraces ADR in relation to the maintenance of peace and order is the Kalinga province because of the presence and practice of bodong. Most of the Kalingas (referring to people) prefer to settle their differences through bodong rather than to undergo the usual legal remedies and proceedings. Stark and Skibbo ${ }^{[4]}$ share that Bodong (peace pact) is a well-codified system of custom of law that links villages and areas to one another through agreements that end tribal conflicts, establishes peaceful areas for commerce and travel and ensures justice for crimes committed. In other words, bodong is a cultural necessity that aims to address and to arrest the tribal conflict between and among villages which may hinder social and economic progress as these intervene in the healthy processes of intermarriage, trade and commerce.

Bodong emerged from the customs and traditions of the Kalingas with a constitution and by-laws known as the pagta. The provisions of the pagta basically highlights the duties, rights and protection of members as well as the sanctions to crimes committed. The bodong holders (village leaders) serve as peace makers when dispute arises and the 
binodngan (member of the bodong) is duty-bound to comply with the set of rules and guidelines of the said practice.

According to Prill-Brett ${ }^{[5]}$, in a study on Cordillera indigenous political institutions, bodong has essential steps to be followed religiously. First is the sipat. It is the exchange of two objects of about equal value between two men who want to establish a peace pact. Second is the simsim, a ritual that is done in the village of the initiator of the pact. Grievances are discussed and announced to the public. Third is the lonok that refers to a large celebration in which the delegates of the other concerned village are invited. The issues are discussed, payment of indemnities is undertaken, and provisions of the pagta are drawn up. Fourth step is the dolnat (to warm up). It is much like alonok where exchange of valuable gifts is done.

As years went by, the Kalingas decided to institutionalize the practice of bodong so that the provisions as well as polices would become binding. Consequently, bodong holders, binodngans and the local government authorities created the Matagoan Bodong Consultative Council. The seat is located in Tabuk, Kalinga, the capital town (now a city) of the province. The institutionalization of bodong, which is practiced by the Matagoan Bodong Consultative Council (MBCC) through Executive Order 2011-01 issued by the city mayor of Tabuk, formalized the merging of the Municipal Bodong Council and Matagoan Consultative Body into one. Recent data of the Matagoan Bodong Consultative Council ${ }^{[6]}$ reveal that from January 1, 2001 to December 31, 2010, one hundred seventy eight (178) crime incidents were recorded by the council. Eighty three (83) were crimes against person, (4) were crimes against property and ninety-nine (99) were violations of special laws and other crimes. The statistics is as follows: (a) twenty- eight (28) murder cases and out of this figure, ten (10) were homicide; (b) forty five (45) Physical Injuries; (c) four (4) Robbery or Theft and (d) ninety-nine (99) other crimes both on crime against person and violation of special laws. All the aforementioned cases were properly resolved and the suspects were all given due penalties as mandated in the provision of the pagta. Although there was an increase in the number of cases, most of these did not escalate into tribal conflict. As an alternative justice system, bodong showcases the fundamental desire of the Kalingas to come up with measure of providing harmony in their society based on their customs that have been passed on conscientiously by their ancestors, Heifer Philippines International ${ }^{[7]}$.

The practice of bodong in Kalinga is sanctioned by several legal bases. United Nations Declaration of Human Rights Article 27, Section $1^{[8]}$ encapsulates the momentous concept of cultural integrity which gives everyone the relative freedom to practice and to enjoy one's way of life without being suppressed and discriminated by others. It is a fundamental right of the communities to actively participate in the process of evolution, conservation, preservation, and enrichment of cultural heritage and artistic traditions.

Furthermore, the Article 12, Section 5 and Article 14, Section 17 of the 1987 Philippine Constitution declare that the State, subject to the provisions of this Constitution and national development policies and programs, shall protect the rights of indigenous cultural communities to their cultures, traditions and ancestral lands to ensure their economic, social, and cultural well-being, De Leon $^{[9]}$. Moreover, the Republic Act 8371commonly known as Indigenous Peoples Rights Act of $1997^{[10]}$ supports the advocacies of indigenous peace framework, multiculturalism and many movements with clear intentions to uphold cultural practice and life-centered traditions that influence everyone's desire in the attainment of a just and humane society.

Hence, these salient concepts prompted the researchers to examine bodong system as alternative dispute resolution in Kalinga province. Specifically, it sought to determine the level of effectiveness of bodong as assessed by the external and internal assessors in terms of the implementation of the provisions reflected in the pagta such as declaration of principles and policies, rights and duties of binodngans, and rights and responsibilities of the bodong holders. The researchers hypothesized that there is no significant difference on the assessment of the groups of respondents regarding the effectiveness of bodong in the above cited variables. Furthermore, the researchers determined the problems encountered in the use of bodong as well as the degree of seriousness of the problems. The ultimate aim of the study was to generate a baseline data as regards the effectiveness of bodong for policy input and for the enhancement of the alternative dispute resolution in the province vis-à-vis local governance and Kalinga peace framework.

\section{Method}

\subsection{Participants}

The 305 respondents of this study were drawn from two (2) major categories namely, the external and internal assessors. There were 236 external assessors. They were the law enforcers of Kalinga province, the court employees of the regional trial court and the municipal trial courts/municipal circuit trial courts and the local chief executives. On the other hand, there were 69 internal assessors composed of the tribe/sub-tribe leaders of the province of Kalinga respectively. Of the total respondents, there were 228 males and 77 females and the age ranged from 50 to 55. All external assessors are professionals and they hold positions in the government sector.

The officers and men of the Kalinga Police Provincial Office comprised the first group of the external assessors with a sample size of 185 . They became part of the external assessors because even though they may not be directly involved in the peace-pact process, they are particularly involved in the solution of crimes and arrest of criminals through information gathering and sometimes mediation, which makes them as observers of the bodong practice.

The employees of the different branches of Municipal 
Trial Courts and Regional Trial Court were the second group of external assessors with a sample size of 42 . They were chosen as respondents because they could determine if bodong really works in unclogging court records most especially in the binodngan areas covered by the Municipal Trial Court or the Municipal Circuit Trial Courts of the towns of Lubuagan, Pasil, Tanudan, Tinglayan and Balbalan.

The last group of the external assessors was the 9 local chief executives that include the Provincial Governor, Mayor of each of the 7 municipalities and the mayor the lone city of Tabuk were. They are the chairpersons of the Peace and Order Council in their own locality. They are responsible in the police intervention in their respective area and in monitoring the influence of bodong in the prevention and solution of crimes.

The different sub-tribe elders in the Matagoan Bodong Consultative Council were the internal assessors. They are the binodngan groups responsible in conducting mediation with the required participants or witnesses on both parties. They also lead in the early resolution of crimes or conflict among sub-tribes and the imposition of penalty to the culprit.

For the group of law enforcers and court employees as external assessors, the sample size of each group was determined using Slovin's formula with five percent $(5 \%)$ margin of error whereas total enumeration was employed for the internal assessors specifically the sub-tribe elders or bodong holders as well as for the subgroup of external assessors referring to the local chief executives. The stratified sampling technique was utilized to identify the respondents for the groups of law enforcers and court employees. This meant that the sample was drawn from the population that was proportionally generated from each group or category.

\subsection{Measures}

A survey questionnaire was floated purposely to obtain responses on the extent of effectiveness of bodong as an alternative dispute resolution. The questionnaire has three (3) parts. Part I elicited information as regards the profile of the respondents in terms of age, sex and position held. Part II contained twenty-six items that were deduced from the provisions of the pagta and reflective of the specific questions of the study. Ten items were made for the declaration of principles and policies. Eight items were indicated for the rights and duties of the binodngans and 8 items were constructed for the rights and duties of the bodong holders. The response format was a 5-point Likert-type scale ranging from 1 (very ineffective) to 5 (very effective). Part III of the questionnaire consisted of 10 items depicting probable problems encountered in the use of bodong. The response format was a 5-point Likert-type scale ranging from 1 (not at all a problem) to 5 (extremely serious). The scale was adopted from Vagias ${ }^{[11]}$; however, few modifications were done to suit to the context of the study.
All the items were translated to Ilokano language since most of the people in Kalinga use this as the lingua franca.

\subsection{Procedure}

The researchers forwarded the Prior and Informed Consent to the officers and members of the Matagoan Bodong Consultative Council, Kalinga Police Provincial Office and the Regional/Municipal Trial Court before the start of the study. During the preliminary survey, the researchers personally explained the purposes of the study to the participants.

Moreover, the researchers conducted a pre-test of the questionnaires in Pinukpuk, Kalinga, a neighboring town of Tabuk City. This was done to determine the flaws of the questions and to allow necessary changes before the official data gathering. The researchers ensured that the participants during the pre-test were not the respondents of the study.

To guarantee 100 percent retrieval, the researchers personally floated the questionnaires considering the rugged roads, distance connecting each municipality and the availability of the respondents especially the sub-tribe leaders. The researchers conducted interviews to validate the responses in the questionnaires. They also employed documentary analysis to scrutinize the organizational records such as the pagta and the cases that were filed and resolved through the Bodong Council.

\section{Results}

The researchers used weighted mean to compute the extent of effectiveness of Bodong and the degree of seriousness of the problems encountered. Moreover, in order to determine the difference of the assessment of internal and external assessors on the effectiveness of bodong, t-test was utilized.

In terms of the effectiveness of bodong, it can be gleaned from Table 1 that among the subgroups of the external assessors, the local chief executives gave the highest evaluation rating. In the implementation of the declaration of principles and policies, rights and duties of the binodngans, and rights and responsibilities of the bodong holders, the weighted mean of the group was 3.84, 3.92 and 3.83 respectively. In general, the external assessors consider bodong to be effective.

On the other hand, the internal assessors gave higher evaluation than the external assessors. The Table 2 shows that the internal assessors consider the implementation or observance of the declaration of principles and policies, and the rights and duties of the binodngans to be very effective with the weighted mean of 4.25 and 4.2 respectively. For them, the rights and responsibilities of the bodong holders were observed effectively. 
Table 1. Table showing the summary of the assessment of external assessors on the level of effectiveness of Bodong as an alternative dispute resolution

\begin{tabular}{|c|c|c|c|c|}
\hline Variables & Groups of External Assessors & Weighted Mean & $\begin{array}{l}\text { Weighted Mean of } \\
\text { All the Groups }\end{array}$ & $\begin{array}{r}\text { Adjectival } \\
\text { Description } \\
\end{array}$ \\
\hline \multirow{3}{*}{$\begin{array}{c}\text { Declaration of } \\
\text { Principles and } \\
\text { Policies }\end{array}$} & Law Enforcers & 3.40 & \multirow{3}{*}{3.86} & \multirow{3}{*}{ Effective } \\
\hline & Court Employees & 3.83 & & \\
\hline & Local Chief Executives & 4.34 & & \\
\hline \multirow{3}{*}{$\begin{array}{l}\text { Rights and Duties } \\
\text { of Binodngans }\end{array}$} & Law Enforcers & 3.37 & \multirow{3}{*}{3.92} & \multirow{3}{*}{ Effective } \\
\hline & Court Employees & 4 & & \\
\hline & Local Chief Executives & 4.4 & & \\
\hline \multirow{3}{*}{$\begin{array}{l}\text { Rights and Duties } \\
\text { of Bodong } \\
\text { Holders }\end{array}$} & Law Enforcers & 3.43 & \multirow{3}{*}{3.83} & \multirow{3}{*}{ Effective } \\
\hline & Court Employees & 3.97 & & \\
\hline & Local Chief Executives & 4.1 & & \\
\hline
\end{tabular}

Legend:

$1.00-1.79$ Very Ineffective (VI)

1.80-2.59 Ineffective (I)

2.60-3.39 Neither Ineffective nor Effective $(\mathrm{N})$

3.40-4.19 Effective (E)

4.20-5.00 Very Effective (VE)

Table 2. Table showing the summary of the assessment of internal assessors on the level of effectiveness of Bodong as an alternative dispute resolution

\begin{tabular}{|c|c|c|}
\hline Variables & Weighted Mean & Adjectival Description \\
\hline Declaration of Principles and Policies & 4.25 & Very Effective \\
\hline Rights and Duties of Binodngans & 4.2 & Very Effective \\
\hline Rights and Duties of Bodong Holders & 4.13 & Effective \\
\hline
\end{tabular}

Legend:

$1.00-1.79$ Very Ineffective (VI)

1.80-2.59 Ineffective (I)

2.60-3.39 Neither Ineffective nor Effective (N)

3.40-4.19 Effective (E)

4.20-5.00 Very Effective (VE)

Table 3. Table showing the comparison on the assessment of external and internal assessors

\begin{tabular}{|c|c|c|c|c|}
\hline Variables & Groups of Assessors & Mean & Standard Deviation & Computed t-value \\
\hline \multirow{2}{*}{$\begin{array}{c}\text { Declaration of Principles } \\
\text { and Policies }\end{array}$} & External Assessors & 34.86 & 9.478 & \multirow{2}{*}{$7.389^{* *}$} \\
\cline { 2 - 4 } & Internal Assessors & 42.35 & 6.677 & \multirow{2}{*}{$5.735^{* *}$} \\
\hline \multirow{2}{*}{$\begin{array}{c}\text { Rights and Duties of } \\
\text { Binodngans }\end{array}$} & External Assessors & 21.11 & 5.833 & 3.611 \\
\cline { 2 - 4 } & Internal Assessors & 24.42 & 9.502 & \multirow{2}{*}{$5.702^{* *}$} \\
\hline \multirow{2}{*}{$\begin{array}{c}\text { Rights and Duties of } \\
\text { Bodong Holders }\end{array}$} & External Assessors & 35.46 & 6.952 & \\
\cline { 2 - 4 } & Internal Assessors & 41.39 & \\
\hline
\end{tabular}

$* *=$ significant at .01

Furthermore, results of the study bare the rejection of the null hypothesis, which points out that there is significant difference on the assessment of the internal and external assessors on the effectiveness of bodong as alternative dispute resolution. As clearly shown in Table 3, the comparison between the assessment of external and internal assessors on the effectiveness of the bodong in terms of the observance of the declaration of principles and policies reveals that the computed $t$-value of 7.389 is significant at 0.01 .

Likewise, the comparison between the assessment of external and internal assessors on the effectiveness of the bodong in terms of the observance of rights and duties of the binodngans reveals a computed t-value of 5.735 which is significant at 0.01 . Corroborative to the data, the comparison between the assessment of external and internal assessors on the effectiveness of bodong in the observance of the rights and responsibilities of the bodong holders evidently shows that the computed $t$-value of 5.702 is significant at 0.01 .

As regards the problems encountered, it can be gleaned from Table 4 that the respondents consider the problems to be "somewhat serious" with the over-all weighted mean of 3.25. Among the groups, only the court employees consider the problems to be moderately serious with a weighted mean 
of 3.52. It is striking to note that in terms of the individual ratings of all the groups of assessors, it discloses that with moderate seriousness, some bodong holders and some binodngans are unaware of the guidelines and procedures which makes them disobedient to comply with the provisions of the pagta, and they are unable to exercise the right and obligation to testify for or against another binodngan in cases filed.

\section{Discussion}

In general, the external assessors consider bodong to be effective in terms of the observance of pagta whereas the sub-tribe elders assess the bodong system to be very effective as Alternative Dispute Resolution (ADR) in Kalinga Province. Cariazo ${ }^{[12]}$ imparts that bodong exists because of the Kalingas' desire to live in peace and social security that advances economic prosperity and social stability. This might be achieved according to the people's concepts of wealth and well-being that they may develop and preserve their very own cultural heritages. The findings explored as cited above would in general lead to a confirmation that bodong plays a very significant role in terms of creating a favorable social image and cultural practices. Kalinga bodong is a socio-cultural and economic institution conceived and painstakingly developed through the centuries out of a need for collective security which is the basis for binding viable communities. It points to the fact that in any attempt to make the community members be united, it just requires cultural norms where people draw their humane identity, stable solidarity and functional mutuality, Bayedyed ${ }^{[13]}$, Sugguiyao ${ }^{[14]}$.

Table 4. Table showing the problems encountered in the use of Bodong

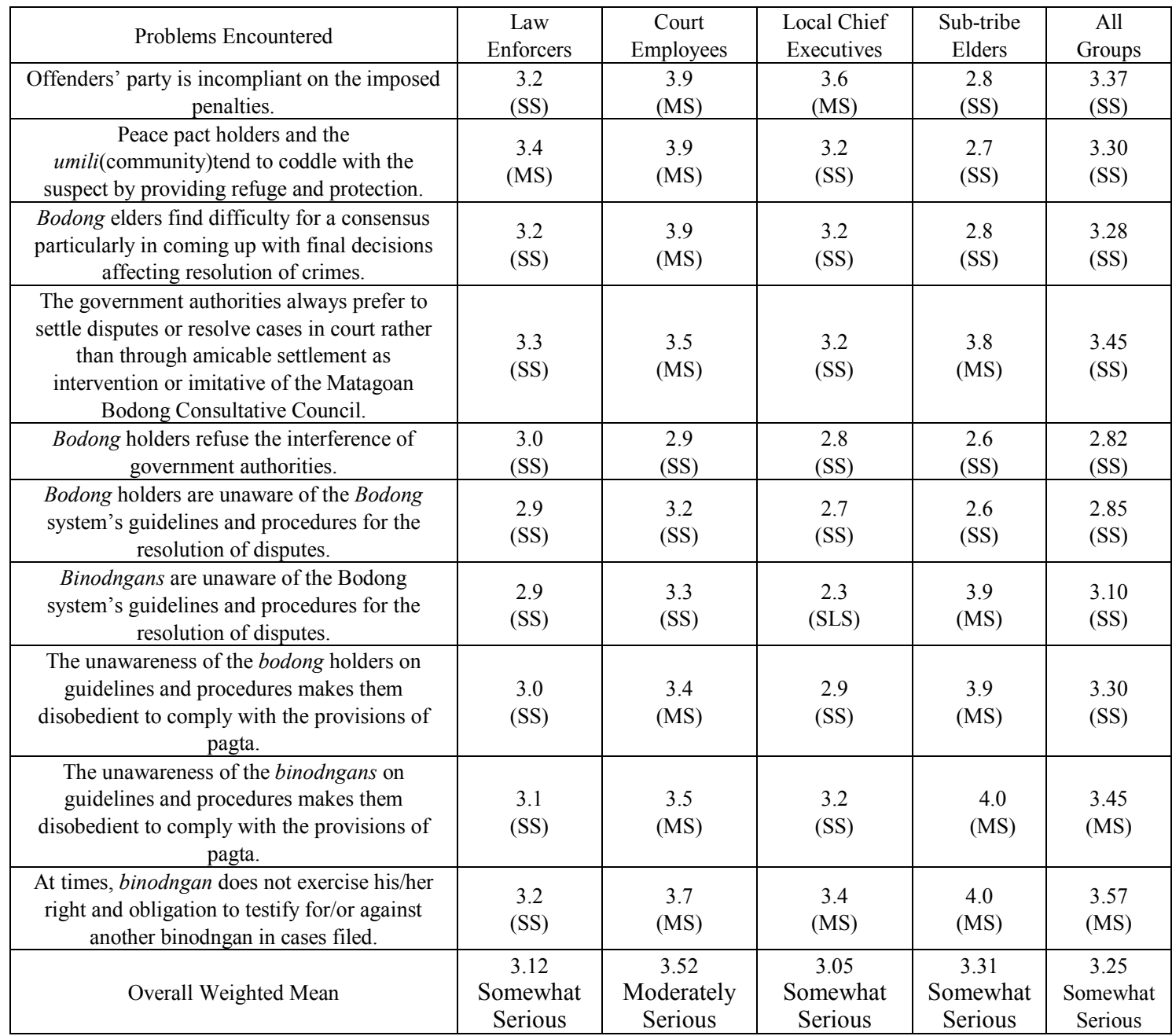

Legend:

1.00-1.79 Not at all a problem (NP)

1.80-2.59 Slightly Serious(SLS)

2.60-3.39 Somewhat Serious (SS)

3.40-4.19 Moderately Serious (MS)

4.20-5.00 Extremely Serious (ES) 
Moreover, bodong is seen by many people in Kalinga including those who are working in the government as effective as it was perceived in the past. In the past, bodong was binding in spite of the reality that the constitution and by-laws were not as extensive and comprehensive as they are today. This manifests now the effectiveness of bodong in keeping the peace and order situation of the province of Kalinga. In fact, in the study of Lang-ay et.al ${ }^{[1]}$, they reveal that specifically, the police personnel strongly agreed on the integration of Kalinga indigenous law in the implementation of modern criminal law in Tabuk City.

In particular, binodngans practice their rights and duties very effectively, as assessed by tribe and sub-tribe elders. Actually, a policeman who is in the performance of his duty may not be liable to bodong on condition that there was no negligence on the performance of his duty and he has not committed violation of the human rights of the victim, whether binodngan or non-binodngan. This finding supports the point cited by Philippine Information Agency (PIA) Kalinga ${ }^{[15]}$ that contrary to the notion that binodngan policemen are ineffective because of their affiliation to the customary practice, they actually discharge their duties according to their mandate as state police. Thus, bodong is not an obstacle in the discharge of a policeman's duty, it only comes in to settle disputes if the involved parties accede to it. The fact that they are from the place is an advantage since they are oriented on the collective consciousness of the people.

It is also evident that external assessors specifically the local chief executives perceived the bodong to be very effective in imposing to the binodngans the practice or adherence of the following rights and duties as stipulated for in the pagta such as: (a) no binodngan is held liable to answer for an offense without due process as specified for in the provision of the pagta;(b) when a case, through the initiative of the parties involved has been settled amicably, said settlement is valid and binding and the case is deemed finally closed;(c) a binodngan has the right and obligation to testify for or against another in every case, and (d) binodngans will not take it against a police man who in the performance of his duty may not be liable to bodong on condition that there was no negligence on the performance of his duty and he has not committed violation of the human rights of the victim or binodngans or non-binodngan.

As per assessment of sub-tribe leaders and elders, bodong is effective in the observance bodong holders' rights and compliance with their duties or responsibilities as it is deemed manifestation of their being legitimate members of the binodngan community and as specified for in the pagta. This is affirmed by the external assessors who see bodong to be effective in terms of protecting the rights and privileges of the bodong holders. This finding bears out the claims that bodong is religiously subscribed to by the peace pact holders especially in exhibiting their intense desire to settle in the most peaceful means the case that they are handling. Peace pact holders assume an immense responsibility in the enforcement of bodong policies specifically in the implementation of its penalties since to be a bodong holder is not a formal conferment but a gained status and they are chosen because they are competent in settling disputes. They command authority as heads of large extended family groups, Aggalo $^{[16]}$, Calsiyao ${ }^{[17]}$, Casal ${ }^{[18]}$. The bodong holders' responsibilities and liabilities are weaved into the fabric of the bodong system. They must do the tasks expected of them without fear and reservation to avoid losing face, integrity, and honor, and consequent family disagreement which will be carried from generation to generation, Sugguiyao ${ }^{[14]}$.

However, there is a part of the practice of the binodngans in terms of their rights and duties which sub-tribe leaders must pay attention to. This specifically refers to the indemnity for a crime committed. This is clearly stipulated in the jurisdiction and discretion of the bodong authorities. This finding implies that bodong leaders necessarily have to rationalize the indemnities and ensure that imposing the indemnities against a crime committed should be in consonant with existing provisions of the Penal Code of the Republic of the Philippines. In this manner, the imposition of the sanction is constructive and just. This is to harmonize with the laws of the land that are highly presumed to be superior over other culturally related guidelines.

Moreover, both the external and internal assessors consider the observance of the rights and duties of the bodong holders to be effective. The findings strongly back up the point of Kalinga Provincial Peace and Order Council Resolution 003 series of $2002^{[19]}$ that cites a resolution requesting all tribal related crimes in the urban barangays of Tabuk, Kalinga Matagoan Zone, particularly in the barangays of Bulanao, Appas, Magsaysay, Dagupan West and Casigayan in the application of Section 1 Article 11 of the proto pagta which aims to solicit the active involvement of the council of elders in mediating between the warring tribes. It emphasizes the role of the council of elders as leaders of their respective tribes and to promote strict adherence to bodong. With these, the PPOC- RPOC expected to come with peaceful settlement of tribal conflicts, better relationship among the different tribes and strict subscription to the Bodong system by the indigenous system tribes of Cordillera.

Furthermore, there is significant difference on the comparison between the assessment of external and internal assessors on the effectiveness of the bodong as alternative dispute resolution with respect to the variables. This simply means that the responses of the two groups differ, with the tribal leaders giving a higher level of assessment than the external assessors. This idea is attributed to the fact that bodong is an internal mechanism which has been proven as effective among immediate constituents in Kalinga province. The finding proves that sub-tribe elders still demonstrate a deep sense of ownership of their practice because they are straightforwardly involved. Besides, the external assessors are not direct participants of the peace pact rituals and processes. Nevertheless, they are somewhat aware of the ins and outs of the bodong based on their observations and 
testimonies. Moreover, they are oriented on the legal aspects of crime resolution which may be different from the principles of bodong.

As regards problems encountered in the use of bodong, in general, the respondents consider them to be somewhat serious. However, it can be noted that some bodong holders and some binodngans, with moderate seriousness, are unaware of the guidelines and procedures which make them disobedient in complying with the provisions of the pagta, and they are unable to exercise the right and obligation to testify for or against another binodngan in cases filed. These circumstances reinforce the remark of Calsiyao ${ }^{[17]}$ that some police and military officers who are binodngans hesitate to execute their duties if their tribe mates hold a bodong with those involved. It can be simply inferred that the somewhat serious problems are actually observed and the guidelines and procedures, rights and obligations, as well as the general provision of the pagta and the legal laws of the Republic of the Philippines are not deliberately embraced by all concerned parties of the binodngan community.

Additionally, in the context of this study, the main basis of determining the effectiveness of the bodong was the perception of the respondents on the observance or implementation of pagta in terms of the declaration of principles and policies, rights and duties of the binodngans and rights and responsibilities of the bodong holders and the assessors were only limited to the local chief executives, court employees, law enforcers and bodong holders. The researchers hope that a parallel study will be undertaken considering other provisions of pagta and binodngans should be included as participants. Besides, a similar study can be done along the dynamics of how other non-Kalinga tribes relate with bodong stakeholders and thereby exploring the underlying value systems integral to bodong from the outsiders' point of view. The study further recommends that in order to sustainably advance social security and economic stability of culturally diverse tribes, key stakeholders should constitute bolder steps in coming up with success indicators on the intensive education campaign regarding the provisions of pagta not only to binodngans but also to non-binodngans.

Lastly, the study generated a baseline data on the effectiveness of bodong as an alternative dispute resolution which were useful for the improvement of the system especially in policy formulation and the enrichment of the processes of the Matagoan Consultative Bodong Council. The study also contributed to the recognition of Kalingas' cultural identity, heritage and integrity which can spur admiration to the richness of cultural diversity and revitalize further the genuine culture, value-laden practices and respectable image of the entire Kalinga society. Truly, bodong does not in any way oppose the existing Philippine legal and judicial mechanisms. In fact, it enhances the delivery of justice because bodong authorities, binodngans and even other stakeholders recognize the practice as an effective mode of sustaining peace and order in the province. It prolifically serves its intention as a peace framework that facilitates in the promotion of common good, security and aspirations of the people both for the binodngans and non-binodngans.

\section{REFERENCES}

[1] Lang-Ay, P. L. D., Martin, J. G. S., Doctor, J. G. P., \& Guidangen, J. S. (2013). Integration of Kalinga Indigenous Law in the Implementation of Modern Criminal Law in Tabuk City. IAMURE International Journal of Social Sciences, 5(1). http://iamure.com/publication/index.php/ijss/ article/view/397 Accessed 13November 2013

[2] Mnookin, R. (1998). Alternative dispute resolution. Harvard Law School John M. Olin Center for Law, economics and Business Discussion Paper Series. Paper

232.http://Isn.nellco.org/harvard_olin/232 Accessed 14 December 2013.

[3] Shavell, S. (1995). Alternative dispute resolution: An economic analysis. J.Legal Stud.,24,1. http://heinoline.org/H $\mathrm{OL} /$ LandingPage?handle=hein.journals/legstud24\&div $=5 \& \mathrm{i}$ $\mathrm{d}=$ \&page $=$ Accessed14 December 2013.

[4] Stark, M. T., \&Skibo, J. M. (2007).A history of the Kalinga ethnoarchaeological project. Archaeological Anthropology: Perspectives on Method and Theory, University of Arizona Press, Tucson, 93-110. http://anthropology.hawaii.edu/Peopl e/Faculty/Stark/pdfs/Stark_and_Skibo_2007.pdf Accessed 10 December 2013

[5] Prill-Brett, J. (1987). A survey of Cordillera indigenous political institutions (Vol. 5).Cordillera Studies Center, University of the Philippines College

Baguio.http://cordillerastudies.upb.edu.ph/downloads/pdf/w orking-papers/CSC\%20Working\%20Paper\%2005.pdf Accessed 12 December 2013.

[6] Matagoan Bodong Consultative Council documents

[7] Heifer Philippines International. Brokering Preace among Tribes: How HPI is helping end hunger and tribal wars in Kalinga.

http://www.heiferphils.org/brokering\%20peace\%20among\% 20tribes.pdf

[8] United Nations Declaration of Human Rights. http://www.un.org/en/documents/udhr/

[9] De Leon, H. (2002) Textbook on the Philippine Constitution. Rex Bookstore.Manila, Philippines.

[10] Indigenous Peoples Rights Act (Republic Act 8371. http://www.mpc.org.ph/index.php?option=com_content\&vie $\mathrm{w}=$ article $\& \mathrm{id}=94 \&$ Itemid $=79$

[11] Vagias, W. (2006). Likert-type scale response anchors. Clemson International Institute for tourism and Research Development, Department of Parks, Recreation and Tourism Management.

http://www.clemson.edu/centers-institutes/tourism/document s/sample-scales.pdf Accessed 7 December 2013.

[12] Cariazo, R. (2007) The Pride of Kalinga. Baguio Midland Courier. http://www.baguiomidlandcourier.com.ph/supplement_articl e7.asp 
[13] Bayedyed, L. (2003). Justice and Peace: The Kalinga Way. http://www.highbeam.com/doc/1G1-112357047.html Accessed 12 December, 2013.

[14] Sugguiyao, M. (1990).The Kalinga hill tribe of the Philippines.Manila: National Center for Culture and the Arts.

[15] Philippine Information Agency Kalinga (2009). Binodngan Policemen are Effective. Cordillera News.

[16] Aggalao, A. (1991). Peace Pact Practices of Kalingas: Its Implication to further Development in the Cordilleras.
Unpublished doctoral dissertation. Saint Paul University, Tuguegarao, Cagayan, Philippines.

[17] Calsiyao, P. (1997). The Kalinga Bodong: Its implication to Peace and Order. Unpublished Master's Thesis. Saint Louis College of Tuguegarao.Tuguegarao, Cagayan.

[18] Casal, G. (2009) Conflict and Consonance. The Filipiniana Archives.

[19] Provincial Peace and Order Council (2002) Resolution 003, Kalinga Province series of 2001-2002 